\title{
The Afro-American Biomphalariae
}

\author{
W Lobato Paraense
}

Departamento de Malacologia, Instituto Oswaldo Cruz-Fiocruz, Av. Brasil 4365, 21040-900 Rio de Janeiro, RJ, Brasil

The reports on the occurrence of African planorbids in South America and of South American species in Africa and Asia are reviewed.

Key words: Biomphalaria glabrata - B. tenagophila - B. straminea

The first report on the occurrence of freshwater molluscs common to South America and Africa was published by Lucena in 1950 . Having received a batch of snails collected in the city of Santos, state of São Paulo, and then collecting personally there, he admitted to be dealing with two species, "none of them belonging to any mollusc known by us". He sent specimens to J Bequaert, of the Museum of Comparative Zoology, Harvard College, Cambridge, who identified them as Biomphalaria alexandrina pfeifferi [sic: this name really applies to two species: Biomphalaria alexandrina (Ehrenberg, 1831) and Biomphalaria pfeifferi (Krauss, 1848)] and Bulinus tropicus, African species that would have been introduced during the slave trade (Bequaert \& Lucena 1951, Lucena 1953).

Before that report several authors had recorded the occurrence of planorbids in Santos. Arantes (1923) studied two autochthonous cases of schistosomiasis, collecting a planorbid identified as probably Planorbis centimetralis Lutz (now B. straminea) by Pirajá da Silva, the discoverer of schistosomiasis in Brazil. Moura (1945) and Pinto (1945) treated it as Australorbis glabratus. According to Coutinho (1949a, b) there would be another unidentified species besides $A$. glabratus, reaffirming soon after (Coutinho 1950) that "assuredly $A$. glabratus exists among us and chiefly in Santos".

Prosecuting his investigation, Lucena sent specimens from Santos to several specialists, who had different opinions.

As for the Biomphalaria, S. Jaeckel, of the Museum of Berlin, admitted that it was Australorbis camerunensis Boettger, of the African Republic of Cameroon, an opinion accepted by Lucena (1956: 82) after examining specimens sent by Jaeckel.

Another consulted malacologist was Dartevelle, who admitted the possibility of confusion by Jaeckel between the planorbid of Santos and the samples in the Museum of Berlin, where no longer existed the type and paratypes of $A$. camerunensis, lost during the bombardment of that city.

E-mail: paraense@ioc.fiocruz.br

Received 25 May 2006

Accepted 26 June 2006
Soon after, Dartevelle asked Lucena to contribute to a jubilean publication homaging $\mathrm{H}$ Schouteden, honorary director of the Museum, adding : "I ask you to add that it was due to the information transmitted by Dr Jaeckel and myself that you perceived that this shell introduced, without doubt, by the slaves was not really Bequaert's $B$. pfeifferi but Boettger's A. camerunensis, of which I myself informed you to have found a form at the Lower Congo".

The identification of the planorbid as A. camerunensis was denied by Boettger, who assured that it was Planorbis lugubris, proposed by Wagner (in Spix \& Wagner 1827) for a planorbid collected by Spix in the Brazilian state of Bahia. But Boettger himself then agreed, according to Lucena (1956), that it was really his A. camerunensis.

Ruiz and Carvalho (1953) identified two species in Santos: A. immunis (Lutz) and A. nigricans (Spix), the former much more frequent and the only one infected with Schistosoma mansoni (Note: immunis and nigricans are really one and the same species, B. tenagophila).

Examining ten samples of the local planorbid (Paraense \& Deslandes 1956) we verified that it was indistinguishable in shell and anatomy (Figs 1, 2, 3) and genetically (crossing tests) from A. nigricans (now B. tenagophila). As to "Bulinus tropicus", it was really Physa acuta, a senior synonym of Physa cubensis, as shown recently by Paraense and Pointier (2003).

An exemplary case is that of a planorbid sent in 1956 by Professor Fraga de Azevedo, director of the Instituto de Medicina Tropical of Lisbon, and identified as Biomphalaria pfeifferi (Krauss), descendant of specimens collected in Sul do Save, province of Mozambique, Portuguese West Africa. The characters of the shell (Fig. 4) and reproductive system (Fig. 5) agreed entirely with those of B. straminea (then called Taphius centimetralis) and those African specimens crossed freely with our centimetralis from Pernambuco.

We communicated that result to Prof. Azevedo, who asked for an article for the Annals of his Institute (Paraense \& Deslandes 1957a), in which, of course, we considered as synonyms the two nominal species and tried to understand the extent of its distribution. Some years later I came to know, by a member of that Institute, that on the occasion of a visit to Pernambuco Prof. Azevedo had brought to Lisbon those planorbids, which contaminated an aquarium of his Institute. In a paper on the synonymy of B. straminea (Paraense 1963) I wrote about this subject: 
"This mistake, regrettable as it was, pointed to the reliability of the anatomic in association with the genetic approach in the systematics of planorbids. In fact, in this case the Brazilian species was recognized, in spite of the mistakes about its name and origin".

In 1956 our colleague Emmanuel Dias, who was trying to control planorbids in Egypt, sent to Dr Frederico Simões Barbosa a batch of Biomphalaria boissyi $(=B$. alexandrina) collected in Cairo, a part of which was intended for me. Barbosa et al. (1956) suceeded in crossing a specimen of boissyi with another of albino B. glabrata (then $A$. glabratus) of Recife, concluding that "the snails from Egypt and Brazil have a common gene pool". Afterwards Barbosa and Carneiro (1957) signalized only two morpho- logical differences between glabrata and boissyi: the absence in boissyi of a spermiduct between the collecting canal of the ovotestis and the seminal vesicle (Fig. 6) and of a longitudinal ridge on the renal tube, characteristic of glabrata.

From the batch sent by E Dias I received seven specimens, unfortunately preserved in alcohol (Paraense \& Deslandes 1957b). On dissection they showed a renal region and a reproductive system identical to those of "Taphius nigricans" (now B. tenagophila), except for the absence (Figs 7,8) of the duct between the ovotestis and the seminal vesicle (Barbosa \& Carneiro's paper was not yet published). The absence of such duct is also noted in Plate I of Malek's (1954) paper on B. boissyi (Fig. 9).

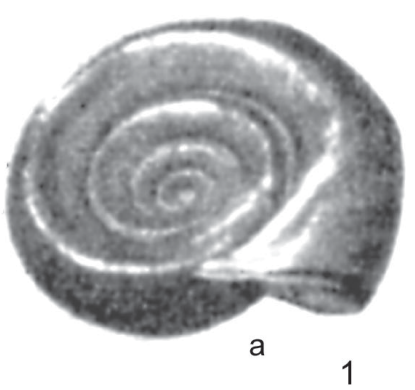

b
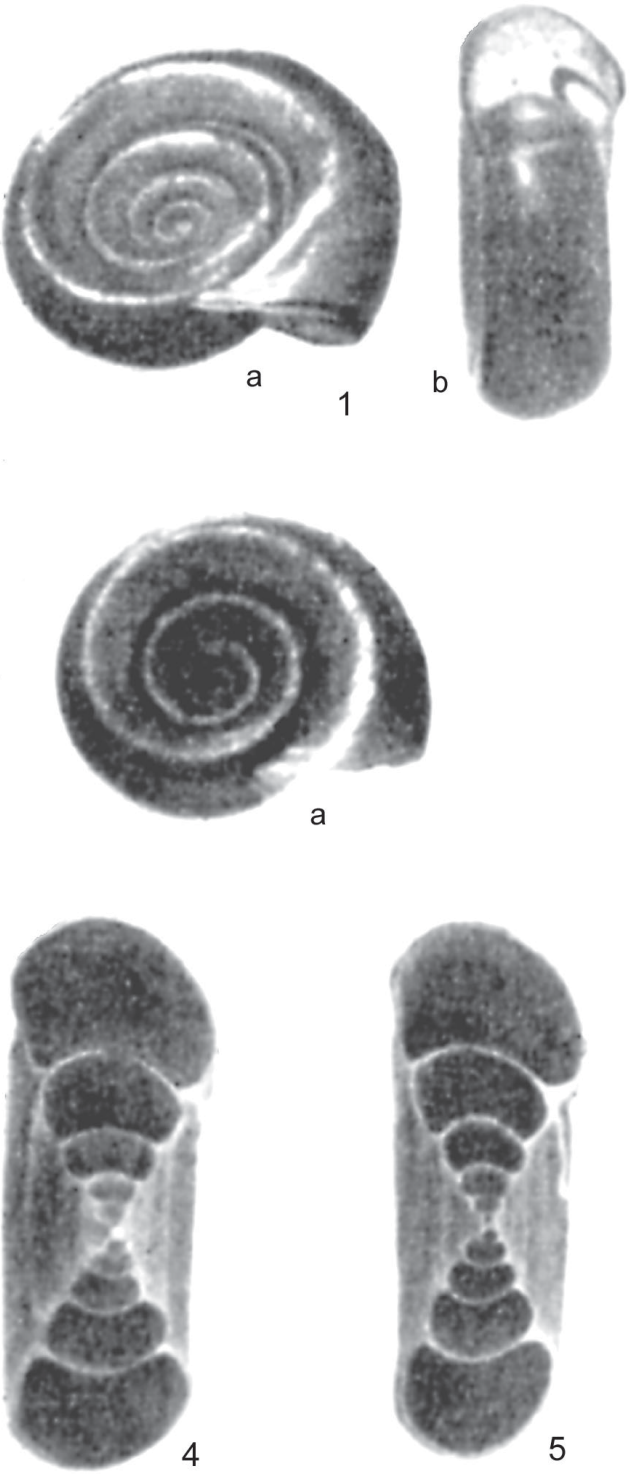

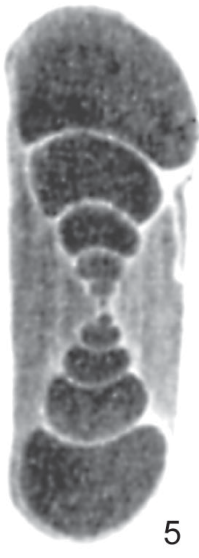

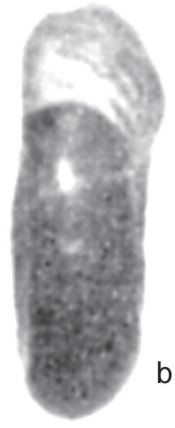
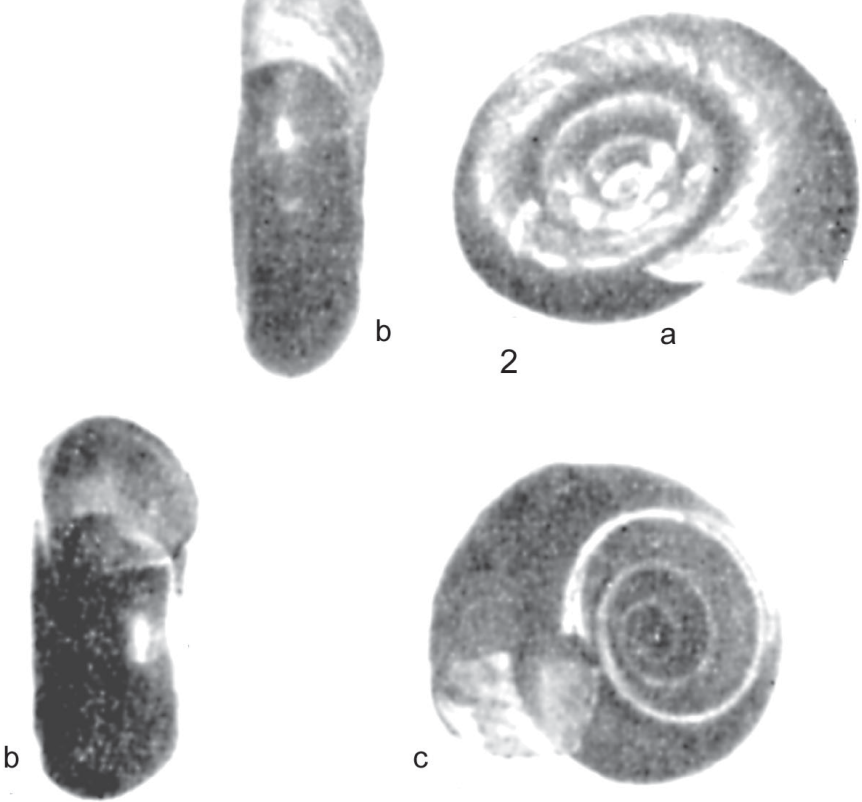

3
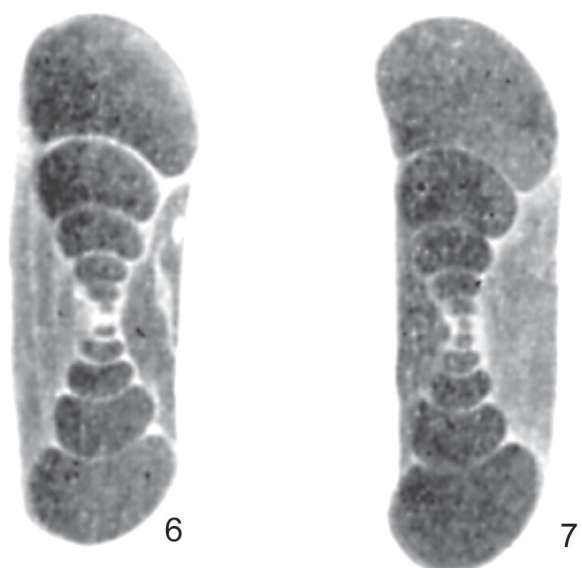

Fig. 1: specimens of Australorbis nigricans (= Biomphalaria tenagophila) from Santos, SP, showing tendency to concavaty of right surface (biconcave forms). 1: usual form, right side strongly depressed; 2 : infrequent flattened variant; 3 : frequent biconcave form; 4: typical biconcave form; 5, 6: intermediate form; 7: infrequent variants tending to planoconcavity. (a: right side; b: front; c: left side). - All figs $\times 2$. 


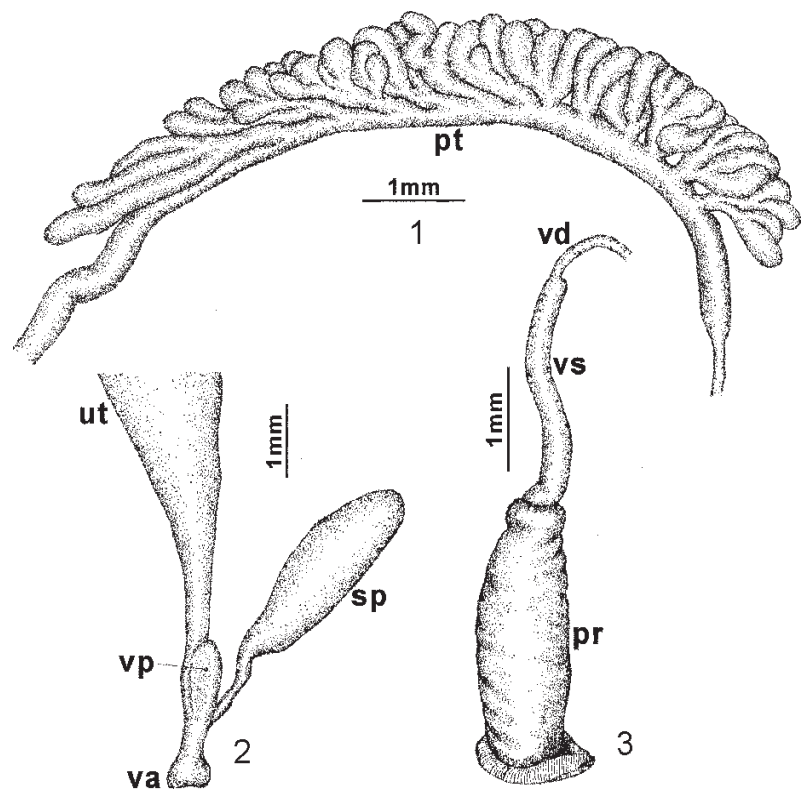

Fig. 2: prostate and copulatory organs of Australorbis nigricans (= Biomphalaria tenagophila) from Santos, SP. 1: prostate from free surface; 2: female copulatory system; 3: male copulatory system.
In December 1981 planorbid snails with typical $B$. glabrata shell, collected at Gaza, west of Cairo, were sent to a research institute in Cairo-Embaba. Commenting on the subject, Pflüger (1982) alerted to the possibility of colonies of that snail kept in African laboratories establishing in the field and of adaptation of local S. mansoni strains to the invader, considered by him endowed with broader ecological tolerance than the local B. alexandrina. Five years later Malek and Yousif (unpublished) collected at Kafr Abu Gomaa village, near Cairo, specimens that they identified as B. glabrata. That finding was mentioned by Yousif et al. (1996), who also found that snail in irrigation and drainage systems at three other localities near Cairo and demonstrated its susceptibility (52\%) to the local strain of S. mansoni. According to Yousif et al. (1998) it hybridized with $B$. alexandrina, the hybrid invaded the irrigation and drainage systems in the Nile delta and the valley north of El-Menya, and both were found infected with S. mansoni.

Kristensen et al. (1999) utilized random amplified polymorphic DNA (RAPD) to differentiate species and populations of Biomphalaria from Egypt and other countries, concluding that "in the Nile Delta B. glabrata as well as $B$. alexandrina is living in the field, and it appears that

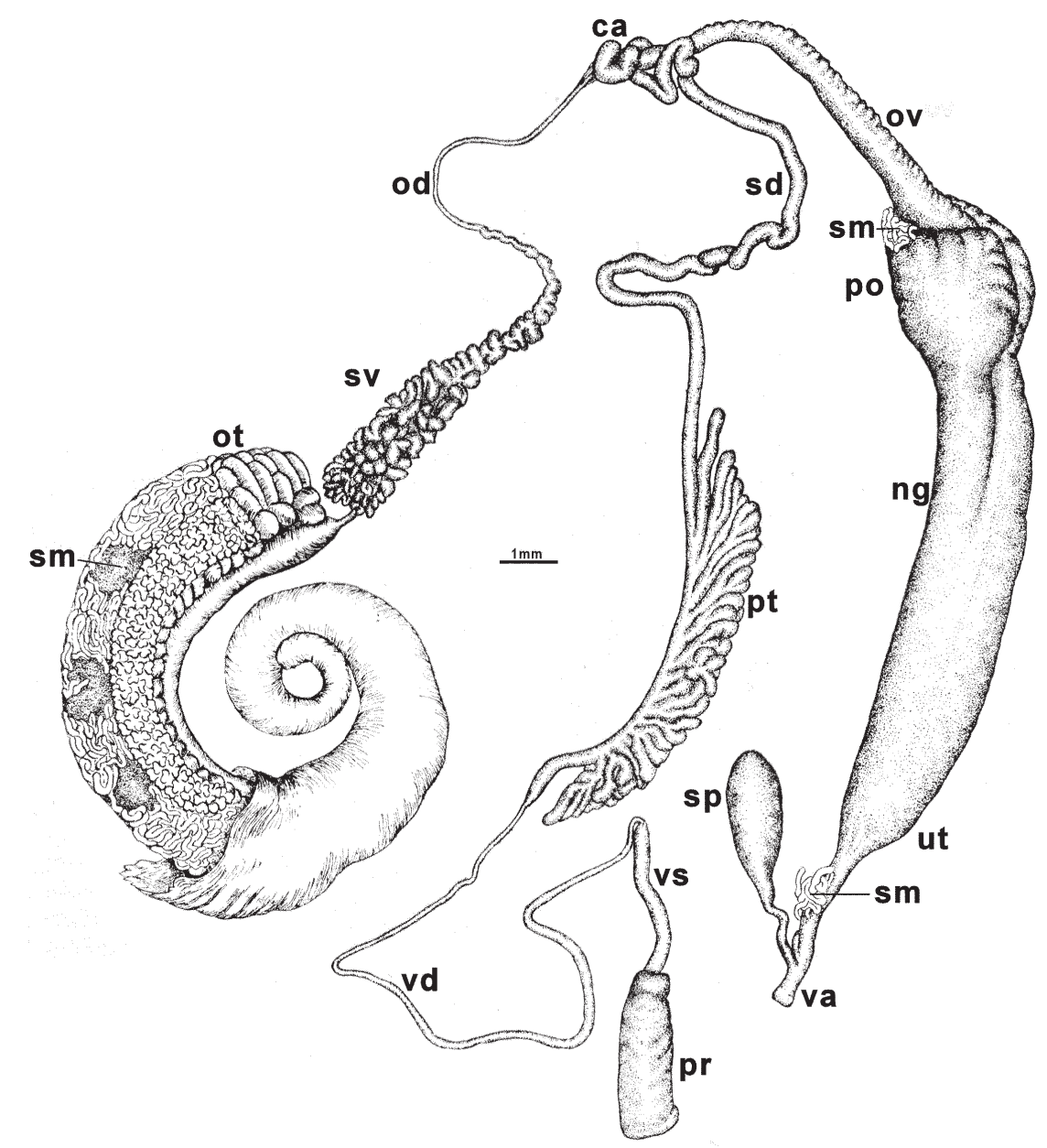

Fig. 3: reprodutive system of infected Australorbis nigricans (= Biomphalaria tenagophila) from Santos, SP. Sporocysts of Schistosoma mansoni (sm) in digestive gland covering ovotestis, and on pouch of oviduct and vagina. 
hybridization may be occurring between the two".

Recently Pointier et al. (2005) recorded the occurrence of B. tenagophila at Kinshasa, Democratic Republic of Congo, based on observations on the morphology of the shell and reproductive system, and molecular characterization (Figs 10, 11).

Contrasting with the above-mentioned findings, all specimens of Biomphalaria collected in 2002-2003 by Lofty et al. (2005) from 37 of 76 localities between the Nile Delta and Lake Nasser were B. alexandrina, according to the results of species-specific polymerase chain reaction assays that sampled both nuclear and mitochondrial genomes, and according to DNA sequence data. These results surprised the authors, because some specimens
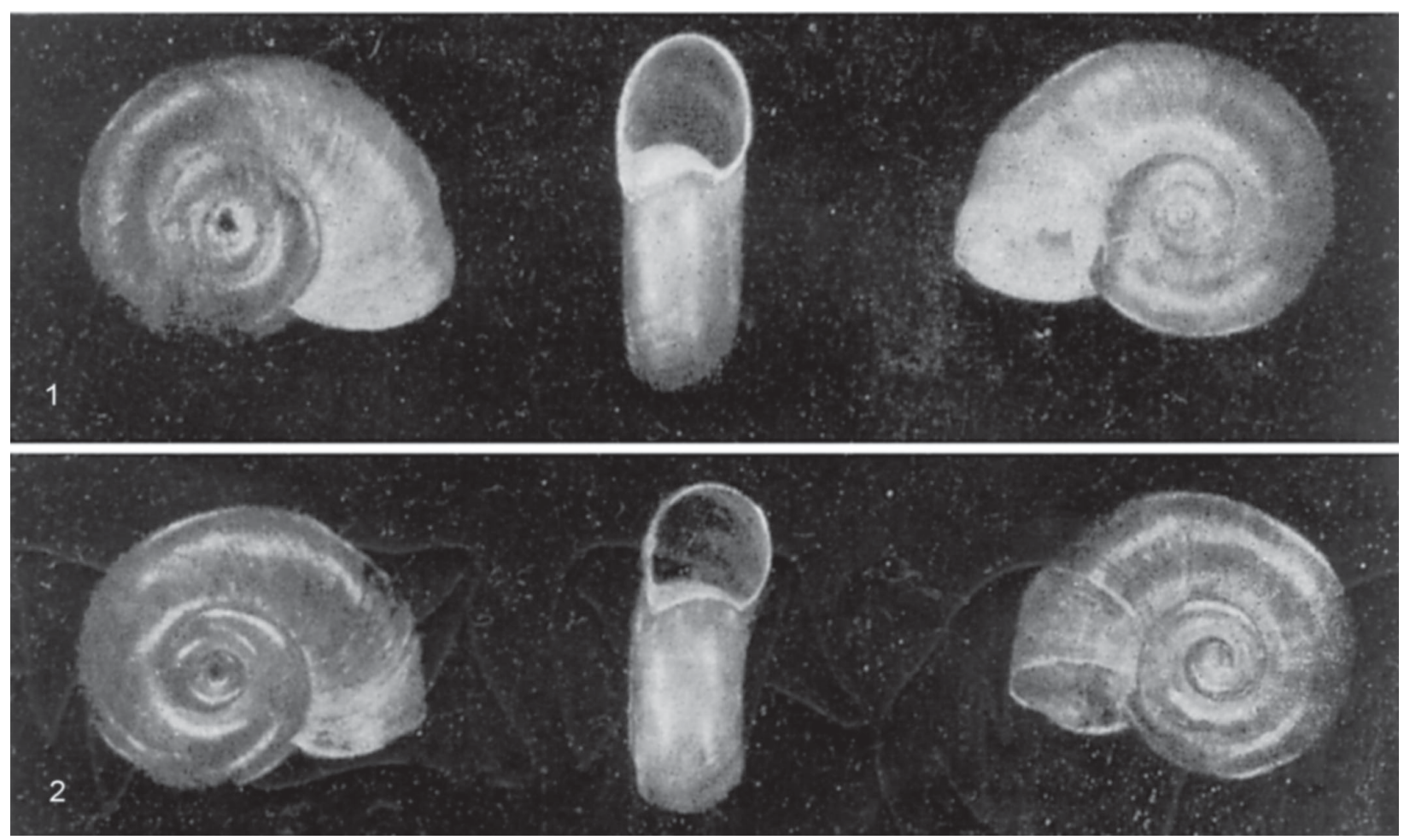

Fig. 4: shell of two "African" specimens received from Prof. Fraga de Azevedo. $\times 3$.

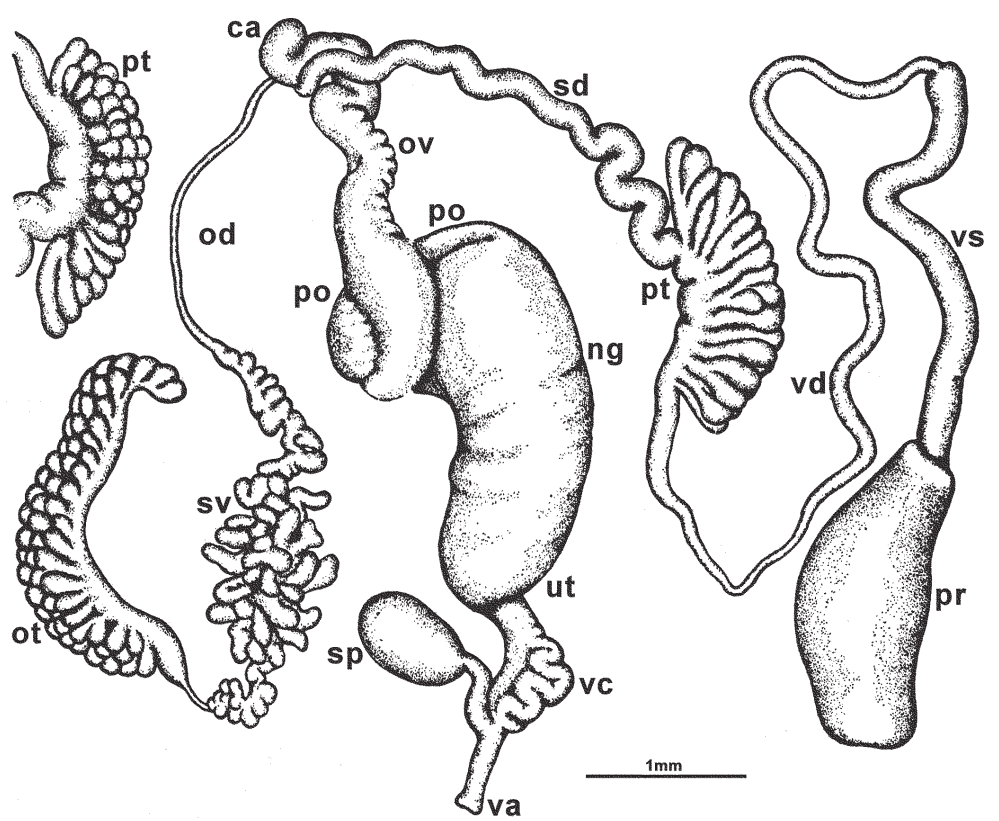

Fig. 5: reprodutive system of "African" specimen. 


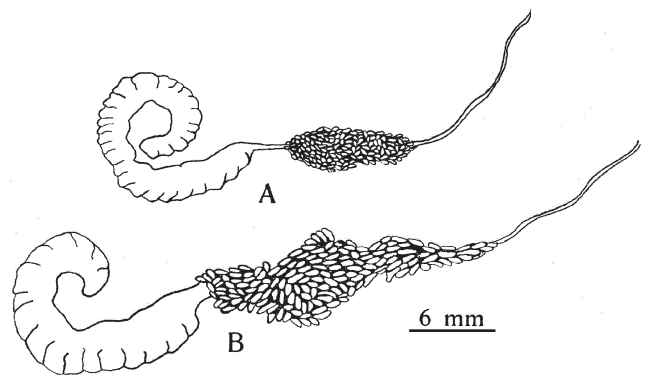

Fig. 6: tha seminal vesicles region in F2 hybrids. A: type glabratus, B: type boissyi. From Barbos \& Carneiro 1957. were, in size and shell, very similar to B. glabrata.

Only exceptionally have the mechanisms involved in the above-mentioned intercontinental displacement been considered. As far as I am acquainted, the only example is that of introduction of $B$. straminea with freshwater plants and fishes in some streams in Hong-Kong (Meier-Brook 1974), with subsequent extension to the mainland (Liu et al. 1982).

As seen above, so far the investigations led to different results. It is desirable that the subject be dealt with integrally, including shell and internal anatomy, crossing experiments and molecular characterization.

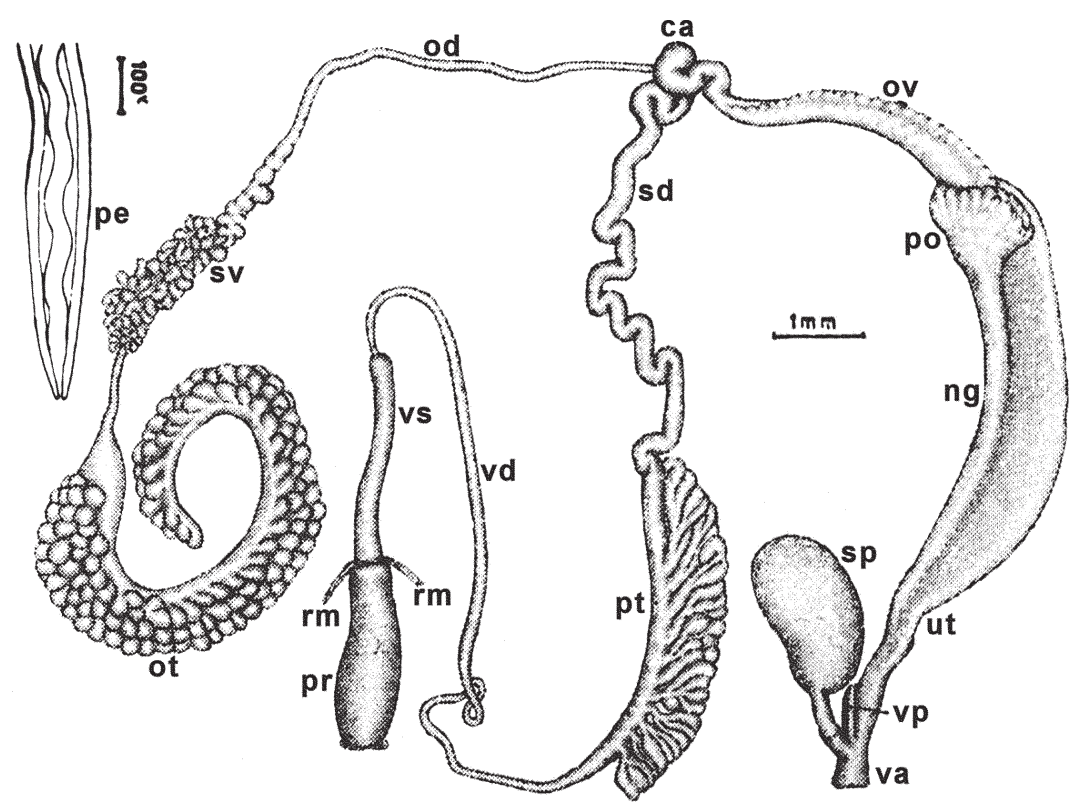

Fig. 7: reproductive system of Taphius nigricans (= Biomphalaria tenegophila).

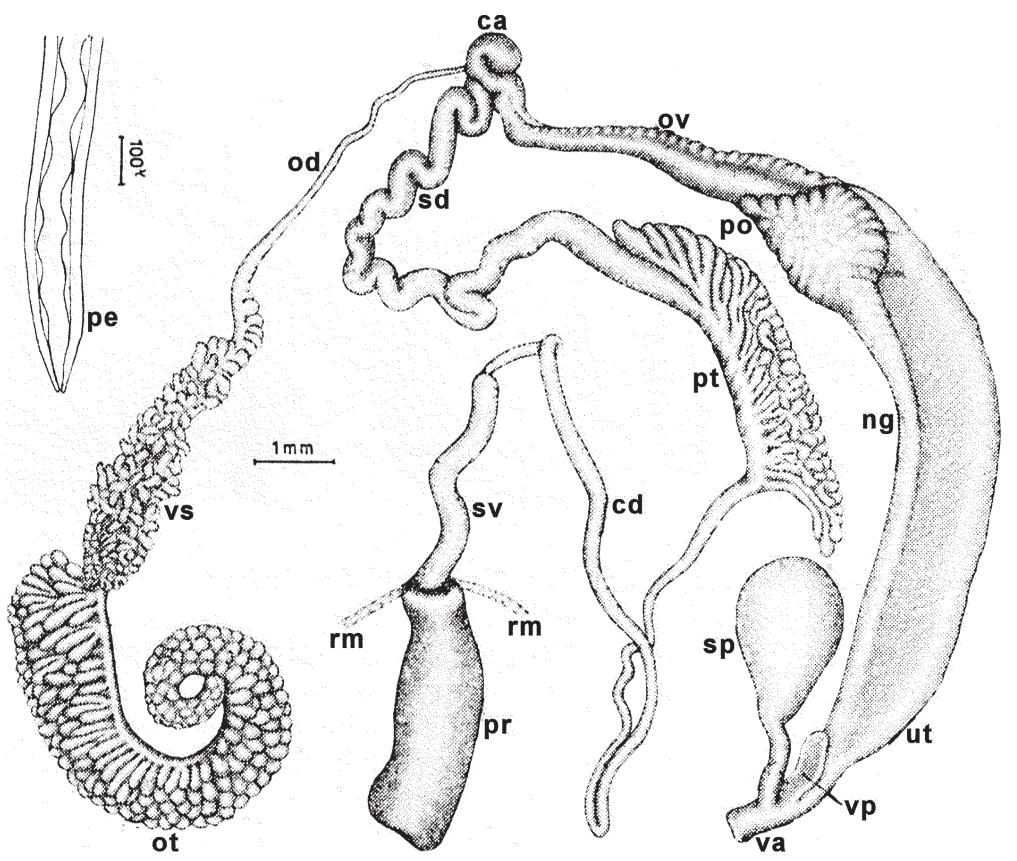

Fig. 8: reproductive system of "Biomphalaria boissyi” from Cairo. 


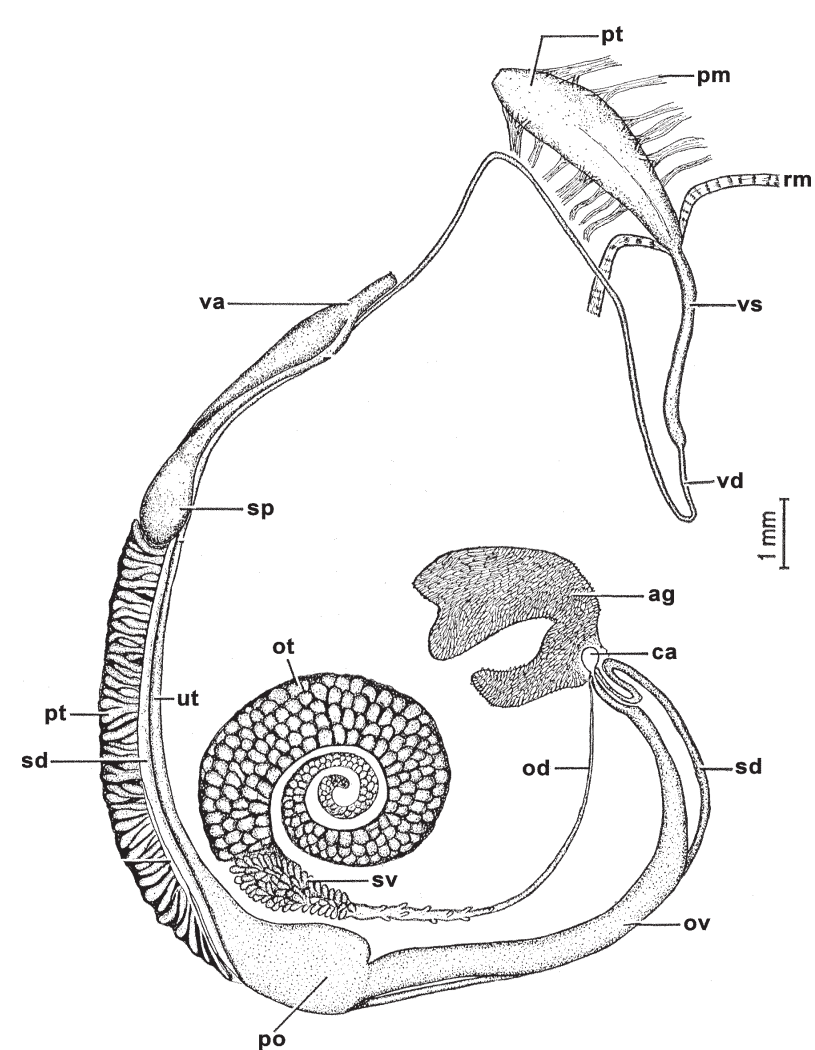

Fig. 9: reproductive system of Biomphalaria boissyi (after Malek 1954).

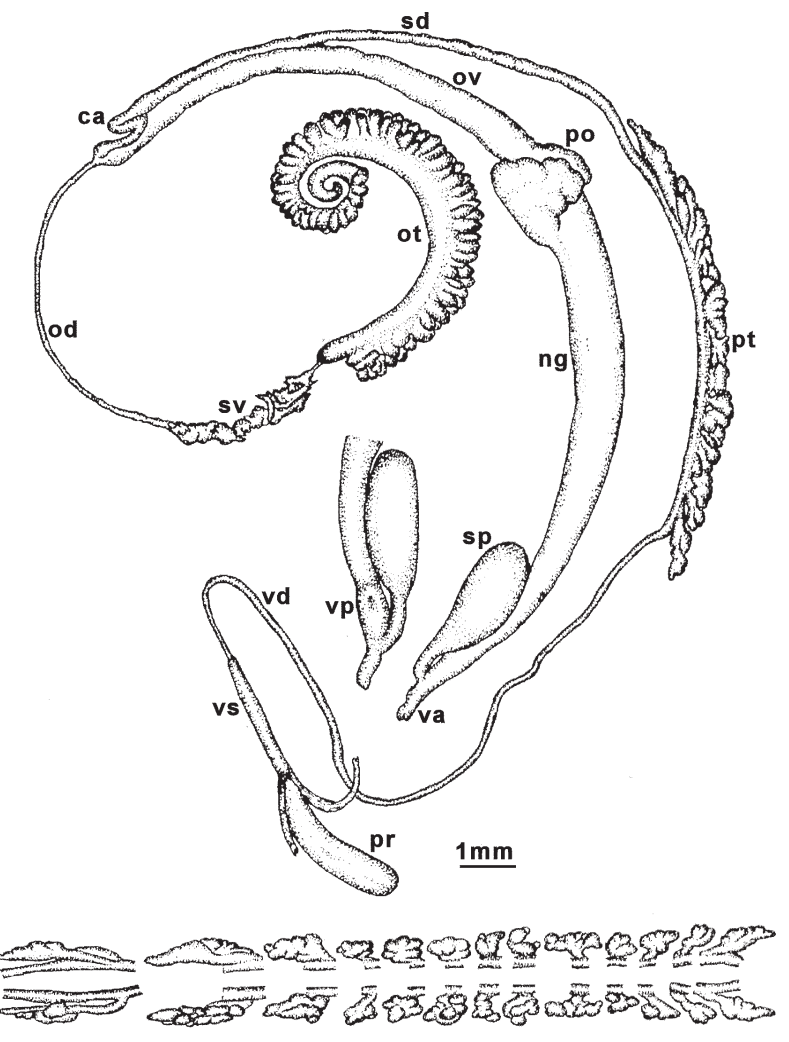

Fig. 10: anatomy of the reproductive system of Biomphalaria collected by Tchuem Tchuenté (1994) in Mangungu River, Kinshsa, DRC (after Pointier et al. 2005).

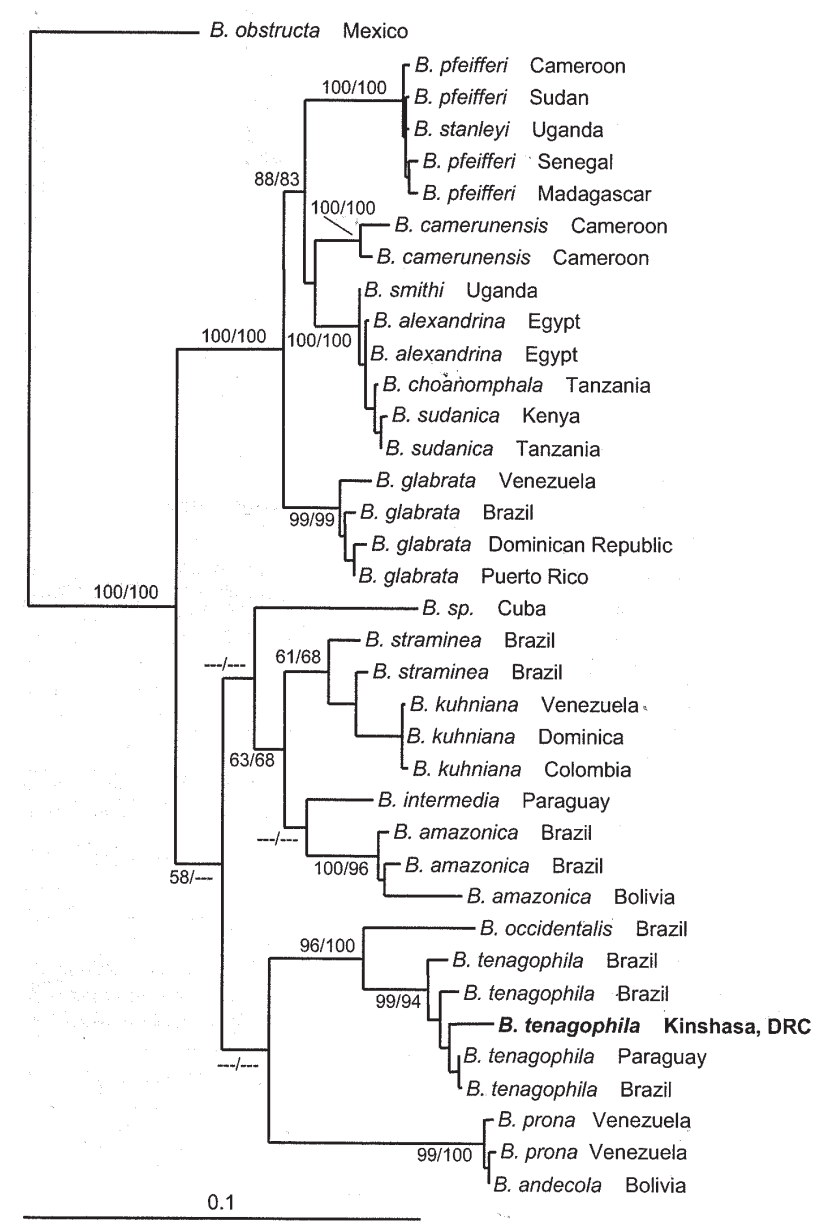

Fig. 11: maximum likelihood tree generated from ITS1, ITS2 and 16S sequence data (Pointier et al. 2005). Bootstrap support values are displayed for major branch nodes (MP/ML); dashes indicate < $50 \%$ support.

\section{LEGEND OF FIGURES}

ag - albumen gland

ca - carrefour

cc - collecting canal

$\mathrm{fd}$ - foremost diverticulum

hd - hindmost diverticulum

ng - nidamental gland

od - ovispermiduct

ot - ovotestis

ov - oviduct

pe - penis

$\mathrm{pm}$ - protractor muscle

po - pouch of oviduct

$\mathrm{pr}-$ prepuce

$\mathrm{pt}$ - prostate

$\mathrm{rm}$ - retractor muscle

sd - spermiduct

sm - sporocysts of Schistosoma mansoni

$\mathrm{sp}$ - spermatheca

sv - seminal vesicles

ut - uterus

va - vagina

$\mathrm{vc}$ - vaginal corrugation

vd - vas deferens

$\mathrm{vp}$ - vaginal pouch

vs - vergic sac 


\section{REFERENCES}

Arantes A 1923. Sobre dois casos de schistosomose autochtones em Santos. An Paul Med Cir 11: 95-96.

Barbosa FS, Carneiro E 1957. The hybrid "glabratus" $x$ "boissyi", with a discussion on the position of the genera "Australorbis" and "Biomphalaria" (Mollusca, Planorbidae). Rev Brasil Biol 17: 43-49.

Barbosa FS, Coelho MV, Carneiro E 1956. Cross-breeding of Australorbis glabratus and Biomphalaria boissyi. Trans $R$ Soc Trop Med Hyg 50: 296.

Bequaert JC, Lucena DT 1951. Introdução no Brasil de duas espécies africanas de caramujos transmissores da esquistossomose. Rev Brasil Med 8: 167-170.

Coutinho JO 1949a. Moluscos do gênero Australorbis Pilsbry, 1934 - (Mollusca Planorbidae). Rev Clin S Paulo 25: 1-6.

Coutinho JO 1949b. Contribuição para o estudo do hospedador intermediário do Schistosoma mansoni em Santos - São Paulo. Rev Clin S Paulo 25: 11-18.

Coutinho JO 1950. Identidade entre o Australorbis glabratus (Say, 1818) de Caracas, Venezuela, e o de Santos, São Paulo, Brasil. Arq Hig Saúde Publ 15: 155-157.

Kristensen TK, Yousif F, Raahauge P 1999. Molecular characterization of Biomphalaria sp. in Egypt. J Mo1 Stud 65: 133-136.

Liu YY, Huang YS, Zhuang WQ 1982. The discovery of Biomphalaria straminea (Dunker), an intermediate host of Schistosoma mansoni, from China. Acta Zootaxon Sinica 7: 256.

Lofty WM, DeJong RJ, Abdel-Kader A, Loker ES 2005. A molecular survey of Biomphalaria in Egypt: is B. glabrata present? Am J Trop Med Hyg 73: 131-139.

Lucena DT 1950. Introdução no país de duas espécies africanas de caramujos transmissores de schistosomose: Bulinus tropicus (Krauss) e Biomphalaria alexandrina pfeifferi (Krauss). Nota preliminar. Rev Brasil MalarioI Doen Trop 2: 276 .

Lucena DT 1953. Sobre um Planorbideo da África ocidental introduzido na América do Sul. Rev Zool Botan Afric 48: 176-178.

Lucena DT 1956. Resenha Sistemática dos Planorbideos Brasileiros, Thesis, Instituto de Educação de Pernambuco, Recife, 104 pp.

Malek ET 1954. Morphological studies on the family Planorbidae (Mollusca: Pulmonata). II. The genital organs of
Biomphalaria boissyi (subfamily Planorbinae, H. A. Pilsbry, 1934). Trans Amer Microsc Soc 73: 285-296.

Meier-Brook C 1974. A snail intermediate host of Schistosoma mansoni introduced into Hong Kong. Bull WHO 51: 661.

Moura SAL 1945. Schistosomose mansoni autoctone em Santos. Rev Inst Adolfo Lutz 5: 279-311.

Paraense WL 1963. The nomenclature of Brazilian planorbids. III. Australorbis stramineus (Dunker, 1848). Rev Brasil Biol 23: 1-7.

Paraense WL, Deslandes N 1956. Australorbis nigricans as the transmitter of schistosomiasis in Santos, State of São Paulo. Rev Brasil Malariol Doen Trop 8: 235-245.

Paraense WL, Deslandes N 1957a. Observations on an AfroSouth American planorbid. An Inst Med Trop 14: 471-482.

Paraense WL, Deslandes N 1957b. Biomphalaria boissyi, synonyme probable de Taphius nigricans. Ann Parasitol Hum Comp 32: 482-490.

Paraense WL, Pointier JP 2003. Physa acuta Draparnaud, 1805 (Gastropoda: Physidae): a study of topotypic specimens. Mem Inst Oswaldo Cruz 98: 513-517.

Pfluger W 1982. Introduction of Biomphalaria glabrata to Egypt and other African countries. Trans R Soc Trop Med Hyg 76: 567.

Pinto C 1945. Sôbre um foco de esquistosomíase mansoni em culturas de agrião (Nasturtium officinale) na cidade de Santos. Rev Brasil Med 2: 820-823.

Pointier JP, DeJong RJ, Tchuenté LAT, Kristensen TK, Loker ES 2005. A neotropical snail host of Schistosoma mansoni introduced into Africa and consequences for the schistosomiasis transmission Biomphalaria tenagophila in Kinshasa (Democratic Republic of Congo). Acia Trop 93: 191-199.

Ruiz JM, Carvalho JM 1953. Australorbis immunis (Lutz, 1918) hospedeiro intermediário de Schistosoma mansoni na cidade de Santos, Estado de São Paulo. Mem Inst Butan$\tan 25$ : 175-176.

Spix JB, Wagner JA 1827. Testacea fluviatilia brasiliensia, C Wolff, Monachii, 36 pp.

Yousif F, Haroun N, Ibrahim A, El-Bardicy S 1996. Biomphalaria glabrata: a new threat for schistosomiasis transmission in Egypt. J Egypt Soc Parasitol 26: 191-205.

Yousif F, Ibrahim A, Kader AA, El-Bardicy S 1998. Invasion of the Nile valley in Egypt by a hybrid of Biomphalaria glabrata and Biomphalaria alexandrina, snail vectors of Schistosoma mansoni. J Egypt Soc Parasitol 28: 569-582. 
